\title{
PENINGKATAN KETERLIBATAN MAHASISWA DALAM PEMBELAJARAN BIOSTATISTIK DENGAN METODE KOOPERATIF MELALUI MEDIA LEMBAR KERJA MAHASISWA (LKM) DI PROGRAM STUDI PERUMAHSAKITAN
}

\author{
Nia Murniati ${ }^{* *}$, Supriadi ${ }^{* *}$, Tri Gunadi ${ }^{* *}$ \\ ${ }^{\prime}$ Program Studi Perumahsakitan Program Vokasi Universitas Indonesia \\ ${ }^{2}$ Program Stud Okupasi Terapi Program Vokas Universtas Indonesia
}

\begin{abstract}
ABSTRAK - Penelitian ini dilatarbelakangi oleh kurang bergairahnya mahasiswa Program Studi Perumahsakitan dalam mengikuti Mata Kuliah Biostatistik, karena metode pembelajarannya tidak membuat mahasiswa menjadi aktif dan partisipatif. Akibatnya Mata Kuliah Biostatistik seringkali meninggalkan beberapa mahasiswa yang terpaksa mengulang kredit karena batas nilai akhirnya tidak mencapai ambang lulus (C). Hal ini tentu saja sangat merugikan mahasiswa yang bersangkutan karena harus mengulang kredit pada tahun berikutnya, mengingat mata kuliah ini tidak ditawarkan setiap semester. Bahkan ada mahasiswa yang harus mengulang hingga saat magang (semester akhir). Penelitian ini adalah penelitian tindakan kelas dengan subyek seluruh mahasiswa RS1 Tahun Akademik 2012/2013 sebanyak 50 orang dengan batasan materi biostatistik ditekankan pada materi probabilitas. Tempat penelitian di Program Vokasi Universitas Indonesia. Hasil penelitian diperoleh pada siklus 1 rata-rata skor tercapai $3770 / 5000=75,4$, siklus 2 rata-rata skor tercapai $4105 / 5000=$ 82,1 dan siklus 3 rata-rata skor tercapai $4585 / 5000=91,7$. Hasil penelitian menyimpulkan bahwa pembelajaran dengan pendekatan metode kooperatif melalui media LKM memiliki dampak positif dalam meningkatkan prestasi belajar mahasiswa yang ditandai dengan peningkatan rata-rata skor tercapai dalam setiap siklus, serta dapat meningkatkan minat dan motivasi belajar mahasiswa yang ditunjukkan dengan meningkatnya aktivitas diskusi di dalam kelas. Peneliti menyarankan dalam melaksanakan pembelajaran dengan pendekatan metode kooperatif melalui media LKM memerlukan persiapan yang cukup matang, sehingga dosen harus mampu menentukan skenario pembelajaran yang benar-benar bisa diterapkan untuk memperoleh hasil yang optimal.
\end{abstract}

Kata kunci: Penelitian Tindakan Kelas, Metode Koopertif, Lembar Kerja Mahasiswa.

\begin{abstract}
This research is motivated by the lack of passionate students of the Program Studi Perumahsakitan Vokasi in the following study courses Biostatistics, because the teaching method does not make the students become active and participate. Consequently Biostatistics courses often leave some students are forced to repeat the due credit limit does not reach the threshold value eventually pass (C) and of course is very detrimental to the student having to repeat the course credit until they intern (last semester). This study is a class act with the entire student subjects RS1 50 people Academic Year 2012/2013 in the University of Indonesia with the material limits of Biostatistics emphasis on material probability. Results were obtained in cycle 1 achieved an average score of 3770/5000 $=75.4$, cycle 2 average scores achieved 4105/5000 = 82.1 and cycle 3 achieved an average score of 4585/5000 $=91.7$. Conclusion The method of cooperative learning approach through the media LKM have a positive impact in improving student achievement is marked by an increase in the average scores achieved in each cycle, and through the media worksheet can increase student interest and motivation shown by increased activity in the classroom discussion. Advice is to carry out a cooperative approach through the media LKM method requires the preparation of a fairly mature, so the lecturer must be able to determine the learning scenario can actually be applied in order to obtain optimal results.
\end{abstract}




\section{PENDAHULUAN}

\section{Latar Belakang}

Mata kuliah Biostatistik merupakan mata kuliah wajib yang harus diambil oleh seluruh mahasiswa Program Vokasi Program Studi Perumahsakitan. Sebagai mata kuliah yang berkaitan dengan data, seringkali mahasiswa kurang bergairah dalam mempelajarinya karena dianggap sulit dan membosankan. Banyak faktor yang mempengaruhi keberhasilan mahasiswa dalam memperoleh nilai akhir mata kuliah ini, diantaranya adalah metode pengajaran yang digunakan dosen.

Dalam kegiatan pembelajaran, peristiwa yang sering terjadi adalah mahasiswa kurang aktif, kurang berpartisipasi, kurang terlibat dan tidak punya inisiatif. Pertanyaan, gagasan maupun pendapat sering tidak muncul. Dosen bersifat otoriter, penyampaian materi searah, menganggap mahasiswa sebagai penerima, pencatat dan mesin perekam. Hal-hal negatif seperti itu seringkali berkontribusi besar terhadap ketidaklulusan mahasiswa terhadap mata kuliah biostatistik sehingga mereka terpaksa mengulang kredit yang sama pada semester berikutnya.

Salah satu upaya meningkatkan peran aktif mahasiswa dalam pembelajaran, perlu dikembangkan metode dan media yang dapat mengoptimalkan kemampuannya. Memberikan kesempatan pada mahasiswa untuk bertukar pendapat, menanggapi pemikiran yang berbeda, menggunakan media, akan dapat mengingat lebih lama mengenai suatu fakta, prosedur, definisi dan teori sehingga dapat memberikan pengalaman belajar yang tidak semata-mata hanya pengalaman belajar biostatistik. Untuk itu peneliti akan mencoba pendekatan metode kooperatif melalui media Lembar Kerja Mahasiswa (LKM) dengan harapan mahasiswa lebih aktif dan mempunyai semangat belajar yang tinggi.

Sebagai mata kuliah wajib yang harus diambil di Program Vokasi Program Studi Perumahsakitan, Biostatistik seringkali meninggalkan beberapa mahasiswa yang terpaksa mengulang kredit karena batas nilai akhirnya tidak mencapai ambang lulus (C). Hal ini tentu saja sangat merugikan mahasiswa yang bersangkutan karena tidak pada setiap semester mata kuliah ini ditawarkan. Beberapa mahasiswa malah harus mengulang kredit mata kuliah ini hingga saat mereka magang (semester akhir). Berdasarkan permasalahan yang dihadapi ini, peneliti mencoba melihat apakah ada kenaikan nilai mahasiswa setelah menggunakan media LKM dengan metode kooperatif dalam proses pembelajaran?

Penelitian yang dilakukan ini adalah penelitian tindakan kelas dengan subyek seluruh mahasiswa RS1 sebanyak 50 orang. Batasan materi biostatistik ditekankan pada materi probabilitas. 


\section{Studi Literatur}

\section{a. Pengertian Penelitian Tindakan Kelas (PTK)}

PTK adalah suatu bentuk kajian yang bersifat reflektif oleh pelaku tindakan yang dilakukan untuk meningkatkan kemantapan rasional dari tindakan mereka dalam melaksanakan tugas, memperdalam pemahaman terhadap tindakan-tindakan yang dilakukan itu, serta memperbaiki kondisi dimana praktek pembelajaran tersebut dilakukan. Tujuan utama dari PTK adalah untuk memperbaiki/meningkatkan praktik pembelajaran secara berkesinambungan, sedangkan tujuan penyertaannya adalah menumbuhkan budaya meneliti di kalangan dosen (Mukhlis, 2000).

Sesuai dengan jenis penelitian yang dipilih, yaitu penelitian tindakan, maka penelitian ini menggunakan model penelitian tindakan dari Kemmis dan Taggart, yaitu berbentuk spiral dari siklus yang satu ke siklus yang berikutnya. Setiap siklus meliputi planning (rencana), action (tindakan), observation (pengamatan), dan reflection (refleksi). Langkah pada siklus berikutnya adalah perncanaan yang sudah direvisi, tindakan, pengamatan, dan refleksi. Sebelum masuk pada siklus 1 dilakukan tindakan pendahuluan berupa identifikasi masalah. Observasi dibagi dalam tiga putaran, yaitu putaran 1, 2 dan 3, dimana masing-masing putaran dikenai perlakuan yang sama (alur kegiatan yang sama) dan membahas satu sub pokok bahasan yang diakhiri dengan tes formatif di akhir masing-masing putaran.
Dibuat dalam tiga putaran dimaksudkan untuk memperbaiki sistem pengajaran yang telah dilaksanakan.

\section{b. Cooperative Learning (CL)}

CL adalah metode belajar berkelompok yang dirancang oleh dosen untuk memecahkan suatu masalah/kasus atau mengerjakan suatu tugas. Kelompok ini terdiri atas beberapa orang mahasiswa, yang memiliki kemampuan akademik yang beragam. Metode ini sangat terstruktur, karena pembentukan kelompok, materi yang dibahas, langkah-langkah diskusi serta produk akhir yang harus dihasilkan, semuanya ditentukan dan dikontrol oleh dosen. Mahasiswa dalam hal ini hanya mengikuti prosedur diskusi yang dirancang oleh dosen. Pada dasarnya CL seperti ini merupakan perpaduan antara teacher-centered dan studentcentered learning. CL bermanfaat untuk membantu menumbuhkan dan mengasah: (a) kebiasaan belajar aktif pada diri mahasiswa; (b) rasa tanggungjawab individu dan kelompok mahasiswa; (c) kemampuan dan keterampilan bekerjasama antar mahasiswa; dan (d) keterampilan sosial mahasiswa.

\section{c. Pembelajaran}

Pembelajaran adalah proses, cara menjadikan orang atau makhluk hidup belajar. Sedangkan belajar adalah berusaha memperoleh kepandaian atau ilmu, berusaha tingkah laku atau tanggapan yang disebabkan oleh pengalaman (KBBI, 1996).

Selaras dengan pernyataan diatas, Soetomo mengemukakan bahwa pembelajaran 


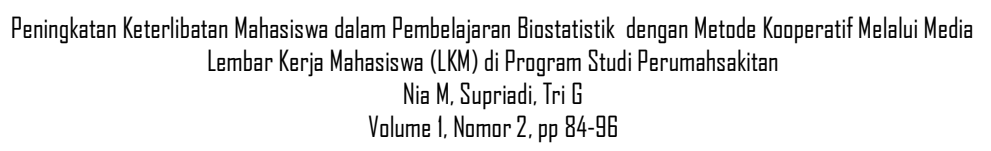

adalah proses pengelolaan lingkungan seseorang yang dengan sengaja dilakukan sehingga memungkinkan dia belajar untuk melakukan atau mempertunjukkan tingkah laku tertentu pula. Sedangkan belajar adalah suatu proses yang menyebabkan tingkah laku yang bukan disebabkan oleh proses pertumbuhan yang bersifat fisik, tetapi perubahan dalam kebiasaan, kecakapan, bertambah, berkembang daya pikir, sikap dan lain-lain (Soetomo, 1993).

Pasal 1 Undang-undang No. 20 Tahun 2003 tentang pendidikan nasional menyebutkan bahwa pembelajaran adalah proses interaksi peserta didik dengan pendidik dan sumber belajar pada suatu lingkungan belajar. Jadi pembelajaran adalah proses yang disengaja yang menyebabkan mahasiswa belajar pada suatu lingkungan belajar untuk melakukan kegiatan pada situasi tertentu.

\section{d. Hasil Belajar}

Hasil belajar mahasiswa adalah nilai yang diperoleh mahasiswa selama kegiatan belajar mengajar. Belajar diartikan sebagai gejala perubahan tingkah laku yang relatif permanen dari seseorang dalam mencapai tujuan tertentu De Cecco (dalam Witjaksono, 1985). Menurut Gagne (dalam Witjksono, 1985) belajar adalah suatu perubahan yang terjadi dalam disposisi atau kapabilitas seseorang, dalam kurun waktu tertentu, dan bukan semata-mata sebagai proses pertumbuhan. Belajar merupakan proses dimana otak atau pikiran mengadakan reaksi terhadap kondisikondisi luar dan reaksi itu dapat dimodifikasi dengan pengalaman-pengalaman yang dialami sebelumnya. Melalui proses belajar anak dapat mengadaptasikan dirinya pada lingkungan hidupnya. Adaptasi itu dapat berupa perubahan pikiran, sikap, dan keterampilan. Selaras dengan pernyataan di atas Bloom menekankan perhatiaannya pada apa yang mesti dikuasai oleh individu. Tujuan belajar yang dikemukakannya dirangkum kedalam tiga kawasan yang terkenal dengan taksonomi Bloom adalah sebagai berikut:

a. Domain kognitiif, terdiri atas 6 tingkatan yaitu:

a. Pengetahuan (mengingat, menghafal)

b. Pemahaman (mengintepretasikan)

c. Aplikasi (menggunakan konsep untuk memecahkan masalah)

d. Analisis (menjabarkan suatu konsep)

e. Sintesis (menggabungkan bagianbagian konsep menjadi suatu konsep utuh)

f. Evaluasi (membandingkan nilai-nilai, ide, metode, dsb)

b. Domain psikomotor, terdiri atas 5 tingkatan yaitu:

a. Peniruan (menirukan gerak)

b. Penggunaan (menggunakan konsep untuk melakukan gerak)

c. Ketepatan (melakukan gerak dengan benar)

d. Naturalisasi (melakukan gerak secara wajar)

c. Domain afektif, terdiri atas 5 tingkatan yaitu:

a. Pengenalan (ingin menerima, sadar akan adanya sesuatu)

b. Merespon (aktif berpartisipasi) 
c. Penghargaan (menerima nilai-nilai, setia kepada nilai-nilai tertentu)

d. Pengorganisasian (menghubunghubungkan nilai-nilai yang dipercayainya)

e. Pengalaman (menjadikan nilai-nilai sebagian bagian dari pola hidupnya)

Hasil belajar yang diukur pada pembelajaran yang berlandaskan kurikulum 2004 meliputi kemampuan kognitif, afektif, dan psikomotor. Maka dosen tidak hanya menilai mahasiswa dari aspek intelektual tetapi kemampuan sosial, sikap mahasiswa selama proses belajar mengajar serta keaktifan mahasiswa dalam kegiatan pembelajaran juga dinilai oleh dosen. Mahasiswa yang telah mengalami pembelajaran diharapkan memilki pengetahuan dan keterampilan baru serta perbaikan sikap sebagai hasil dari pembelajaran yang telah dialami mahasiswa tersebut. Pengukuran hasil belajar bertujuan untuk mengukur tingkat pemahaman mahasiswa dalam menyerap materi. Sebaiknya hasil belajar yang telah dinilai oleh dosen diberitahukan kepada mahasiswa agar mahasiswa mengetahui kemajuan belajar yang telah dilakukannya serta kekurangan yang masih perlu diperbaiki.

Penilaian hasil belajar pada akhirnya sebagai bahan refleksi mahasiswa mengenai kegiatan belajarnya dan refleksi dosen terhadap kemampuan mengajarnya serta mengevaluasi pencapaian target kurikulum. Benjamin S. Bloom dalam Taxonomy of
Education Objectives membagi hasil belajar kedalam tiga ranah:

\section{Ranah Kognitif}

Ranah kognitif (berkaitan dengan daya piker, pengetahuan, dan penalaran) berorientasi pada kemampuan mahasiswa dalam berfikir dan bernalar yang mencakup kemampuan mahasiswa dalam mengingat sampai memecahkan masalah, yang menuntut mahasiswa untuk menggabungkan konsepkonsep yang telah dipelajari sebelumnya. Ranah kognitif ini berkenaan dengan prestasi belajar dan dibedakan dalam enam tahapan, yaitu pengetahuan, pemahaman, penerapan, analsisi, sintesis, dan eveluasi. Pada mahasiswa SMP diutamakan pada ranah pengetahuan, pemahaman, dan penerapan. Pengetahuan mencakup kemampuan mengingat tentang hal yang telah dipejari, dan tersimpan dalam ingatan. Pengetahuan itu berkenaan dengan fakta, peristiwa, kaidah, prinsip, teori, dan rumus. Pengetahuan yang telah tersimpan dalam ingatan, digali pada saat dibutuhkan dalam bentuk mengingat (recall) atau mengenal kembali (recognition).

Pemahaman mencakup kemampuan untuk menyerap makna dan arti dari bahan yang dipelajari. Kemampuan seseorang dalam memahami sesuatu dapat dilihat dari kemampuaannya menyerap suatu materi, kemudian mengkomunikasikannya dalam bentuk lainnya dengan kata-kata sendiri.

Penerapan mencakup kemampuan untuk menerapkan pengetahuan yang telah diperoleh dalam kegiatan pembelajaran untuk menghadapi situasi baru dalam kehidupan 
sehari-hari. Tingkat penerapan ini dapat diukur dari kemampuan menggunakan konsep, prinsip, teori, dan metode untuk menghadapi masalah-masalah dalam kehidupan sehari-hari.

\section{Ranah Psikomotor}

Ranah psikomotor berorientasi kepada ketrampilan fisik, keterampilan motorik, atau keterampilan tangan yang berhubungan dengan anggota tubuh atau tindakan yang memerlukan koordinasi antara syaraf dan otot. Simpson (dalam Winkel, 1996) menyatakan bahwa ranah psikomotor terdiri dari tujuh jenis perilaku yaitu: persepsi, kesiapan, gerakan terbimbing, gerakan yang terbiasa, gerakan kompleks, penyesuaian pola gerakan, dan kreativitas. Sedangkan menurut Kibler, Barker, dan Miles (dalam Dimyati dan Mudjiono, 1994) ranah psikomotor mempunyai taksonomi sebagai berikut:

a. Gerakan tubuh yang mencolok, merupakan kemampuan gerakan tubuh yang menekankan kepada kekuatan, kecepatan, dan ketepatan tubuh yang mencolok.

b. Ketepatan gerakan dikordinasikan, merupakan ketrampilan yang berhubungan dengan gerakan mata, telinga, dan badan.

c. Perangkat komunikasi non verbal, merupakan kemampuan mengadakan komunikasi tanpa kata

d. Kemampuan berbicara, merupakan kemampuan yang berhubungan dengan komunikasi secara lisan. Untuk kemampuan berbicara, mahasiswa harus mampu menunjukkan kemahirannya memilih dan menggunakan kata atau kalimat sehingga informasi, ide, atau yang dikomunikasikannya dapat diterima secara mudah oleh pendengarnya.

\section{Ranah Afektif}

Ranah afektif (berkaitan dengan perasaan/kesadaran, seperti perasaan senang atau tidak senang yang memotivasi seseorang untuk memilih apa yang disenangi) berorientasi pada kemampuan mahasiswa dalam belajar menghayati nilai objek-objek yang dihadapi melalui perasaan, baik objek itu berupa orang, benda maupun peristiwa. Ciri lain terletak dalam belajar mengungkapkan perasaan dalam bentuk ekspresi yang wajar. Menurut Krochwall Bloom (dalam Winkel 1996) ranah afektif terdiri dari penerimaan, partisipasi, penilaian, dan penentuan sikap, organisasi, dan pembentukan pola hidup. Untuk ranah kognitif, dosen menilai kemampuan kognitif mahasiswa berdasarkan hasil tes yang diberikan kepada mahasiswa pada akhir pelaksanaan siklus 1 dan 2 .

\section{Metode Penelitan}

\section{a. Subjek Penelitian}

Subjek penelitian tindakan kelas ini adalah seluruh mahasiswa (50 orang) kelas RS1 Program Vokasi Program Studi Perumahsakitan Tahun Akademik 2012/2013.

\section{b. Tempat Penelitian}

Tempat penelitian di Program Vokasi Universitas Indonesia. 


\section{c. Prosedur Penelitian}

Langkah-langkah penelitian tindakan kelas dapat dilihat pada bagan alir berikut ini:

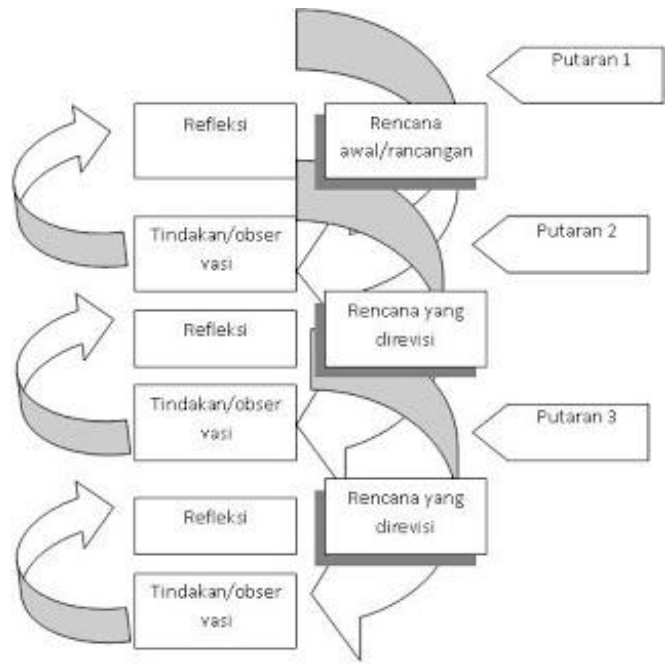

d. Instrumen Penelitian

Instrumen yang digunakan dalam penelitian ini terdiri dari:

a. Silabus

Yaitu seperangkat rencana dan pengaturan tentang kegiatan pembelajaran pengelolahan kelas, serta penilaian hasil belajar.

b. Satuan Acara Perkuliahan (SAP)

Yaitu merupakan perangkat pembelajaran yang digunakan sebagai pedoman dosen dalam mengajar dan disusun untuk tiap putaran. Masing-masing SAP berisi kompetensi dasar, indicator pencapaian hasil belajar, tujuan pembelajaran khusus, dan kegiatan belajar mengajar.

c. Lembar Kerja Mahasiswa (LKM)

Lembar kerja ini yang dipergunakan mahasiswa untuk membantu proses pengumpulan data hasil eksperimen.

d. Lembar Observasi Kegiatan Belajar Mengajar a. Lembar observasi pengolahan metode pembelajaran demonstrasi, untuk mengamati kemampuan dosen dalam mengelola pembelajaran.

b. Lembar observasi aktivitas mahasiswa dan dosen, untuk mengamati aktivitas mahasiswa dan dosen selama proses pembelajaran.

e. Tes formatif

Tes ini disusun berdasarkan tujuan pembelajaran yang akan dicapai. Tes formatif ini diberikan setiap akhir putaran. Bentuk soal yang diberikan adalah essay terbatas.

\section{e. Metode Pengumpulan Data}

Data-data yang diperlukan dalam penelitian ini diperoleh melalui observasi aktivitas mahasiswa dan dosen, serta tes formatif.

\section{f. Teknik Analisis Data}

Untuk mengetahui keefektivan suatu metode dalam kegiatan pembelajaran perlu diadakan analisis data. Pada penelitian ini menggunakan teknik analisis deskriptif, yaitu suatu metode penelitian yang bersifat menggambarkan kenyataan atau fakta sesuai dengan data yang diperoleh dengan tujuan untuk mengetahui prestasi belajar yang dicapai mahasiswa juga untuk memperoleh respon mahasiswa terhadap kegiatan pembelajaran serta aktivitas mahasiswa selama proses pembelajaran. Untuk mengalisis tingkat keberhasilan atau persentase keberhasilan mahasiswa setelah proses belajar mengajar setiap putarannya 
dilakukan dengan cara memberikan evaluasi berupa soal tes tertulis pada setiap akhir putaran.

Analisis ini dihitung dengan menggunakan statistik sederhana yaitu:

1. Untuk menilai tes formatif

Peneliti melakukan penjumlahan nilai yang diperoleh mahasiswa, yang selanjutnya dibagi dengan jumlah mahasiswa yang ada di kelas tersebut sehingga diperoleh rata-rata tes formatif.

$$
\mathrm{R}=\frac{\sum x}{\mathrm{~N}}
$$

\section{Dimana:}

$R=$ Nilai rata-rata mahasiswa

$\Sigma \mathrm{x}=$ Jumlah semua nilai mahasiswa

$\mathrm{N}=$ Jumlah mahasiswa

\section{HASIL PENELITIAN}

\section{Analisis Data Penelitian Persiklus}

\section{a. Siklus I}

1. Tahap Perencanaan
Pada tahap ini peneliti mempersiapkan perangkat pembelajaran yang terdiri dari rencana pelajaran 1, LKM 1, soal tes formatif 1, dan alat-alat pengajaran yang mendukung.

2. Tahap Kegiatan dan Pelaksanaan

Pelaksanaan kegiatan belajar mengajar untuk siklus I dilaksanakan pada tanggal 11 Maret 2013 di kelas RS1 dengan jumlah mahasiswa 50 orang. Dalam hal ini peneliti bertindak sebagai dosen. Adapun proses belajar mengajar mengacu pada rencana pembelajaran yang telah disiapkan. Pengamatan dilaksanakan bersamaan dengan pelaksanaan belajar mengajar. Pada akhir proses pembelajaran mahasiswa diberi tes formatif I dengan tujuan untuk mengetahui tingkat keberhasilan mahasiswa dalam proses belajar mengajar yang telah dilakukan. Adapun data hasil penelitian pada siklus I adalah sebagai berikut:

Tabel 1.1

Hasil Tes Formatif Mahasiswa Pada Siklus I

\begin{tabular}{|c|c|}
\hline No & Nilai \\
\hline 1 & 70 \\
\hline 2 & 60 \\
\hline 3 & 70 \\
\hline 4 & 80 \\
\hline 5 & 90 \\
\hline 6 & 60 \\
\hline 7 & 60 \\
\hline 8 & 70 \\
\hline 9 & 65 \\
\hline 10 & 70 \\
\hline
\end{tabular}

\begin{tabular}{|c|c|}
\hline No & Nilai \\
\hline 26 & 60 \\
\hline 27 & 50 \\
\hline 28 & 55 \\
\hline 29 & 60 \\
\hline 30 & 60 \\
\hline 31 & 50 \\
\hline 32 & 60 \\
\hline 33 & 80 \\
\hline 34 & 80 \\
\hline 35 & 90 \\
\hline
\end{tabular}




\begin{tabular}{|c|c|}
\hline No & Nilai \\
\hline 11 & 60 \\
\hline 12 & 80 \\
\hline 13 & 90 \\
\hline 14 & 80 \\
\hline 15 & 90 \\
\hline 16 & 70 \\
\hline 17 & 75 \\
\hline 18 & 60 \\
\hline 19 & 65 \\
\hline 20 & 90 \\
\hline 21 & 95 \\
\hline 22 & 90 \\
\hline 23 & 80 \\
\hline 24 & 80 \\
\hline 25 & 85 \\
\hline
\end{tabular}

\begin{tabular}{|c|c|}
\hline No & Nilai \\
\hline 36 & 90 \\
\hline 37 & 95 \\
\hline 38 & 80 \\
\hline 39 & 85 \\
\hline 40 & 85 \\
\hline 41 & 90 \\
\hline 42 & 95 \\
\hline 43 & 95 \\
\hline 44 & 90 \\
\hline 45 & 65 \\
\hline 46 & 60 \\
\hline 47 & 90 \\
\hline 48 & 65 \\
\hline 49 & 90 \\
\hline 50 & 65 \\
\hline
\end{tabular}

Jumlah Skor 3770

Jumlah Skor Maksimal 5000

Rata-Rata Skor Tercapai 3770/5000

$$
=75,4
$$

\section{b. Siklus II}

1. Tahap perencanaan

Pada tahap ini peneliti mempersiapkan perangkat pembelajaran yang terdiri dari rencana pelajaran 2 , LKM 2, soal tes formatif II, dan alat-alat pengajaran yang mendukung.

2. Tahap kegiatan dan pelaksanaan

Pelaksanaan kegiatan belajar mengajar untuk siklus II dilaksanakan pada tanggal 18 Maret 2013 di kelas RS1 dengan jumlah mahasiswa 50 orang. Dalam hal ini peneliti bertindak sebagai dosen. Adapun proses belajar mengajar mengacu pada rencana pembelajaran dengan memperhatikan revisi pada siklus I, sehingga kesalahan atau kekurangan pada siklus I tidak terulang lagi. Observasi dilaksanakan bersamaan dengan pelaksanaan belajar mengajar. Pada akhir proses pembelajaran mahasiswa diberi tes formatif II dengan tujuan untuk mengetahui tingkat keberhasilan mahasiswa. Instrument yang digunakan adalah tes formatif II. Adapun data hasil penelitian pada siklus II adalah sebagai berikut: 
Tabel 1.2

Hasil Tes Formatif Mahasiswa Pada Siklus II

\begin{tabular}{|c|c|}
\hline No & Nilai \\
\hline 1 & 75 \\
\hline 2 & 65 \\
\hline 3 & 75 \\
\hline 4 & 95 \\
\hline 5 & 90 \\
\hline 6 & 65 \\
\hline 7 & 75 \\
\hline 8 & 75 \\
\hline 9 & 80 \\
\hline 10 & 70 \\
\hline 11 & 70 \\
\hline 12 & 85 \\
\hline 13 & 90 \\
\hline 14 & 85 \\
\hline 15 & 95 \\
\hline 16 & 75 \\
\hline 17 & 80 \\
\hline 18 & 65 \\
\hline 19 & 70 \\
\hline 20 & 90 \\
\hline 21 & 95 \\
\hline 22 & 90 \\
\hline 23 & 90 \\
\hline 24 & 90 \\
\hline 25 & 90 \\
\hline
\end{tabular}

\begin{tabular}{|c|c|}
\hline No & Nilai \\
\hline 26 & 80 \\
\hline 27 & 70 \\
\hline 28 & 65 \\
\hline 29 & 65 \\
\hline 30 & 75 \\
\hline 31 & 70 \\
\hline 32 & 70 \\
\hline 33 & 80 \\
\hline 34 & 90 \\
\hline 35 & 90 \\
\hline 36 & 90 \\
\hline 37 & 95 \\
\hline 38 & 85 \\
\hline 39 & 90 \\
\hline 40 & 90 \\
\hline 41 & 90 \\
\hline 42 & 95 \\
\hline 43 & 100 \\
\hline 44 & 100 \\
\hline 45 & 75 \\
\hline 46 & 75 \\
\hline 47 & 90 \\
\hline 48 & 85 \\
\hline 49 & 95 \\
\hline 50 & 70 \\
\hline
\end{tabular}

Jumlah Skor 4105

Jumlah Skor Maksimal 5000

Rata-Rata Skor Tercapai 4105/5000 = 82,1

formatif III, dan alat-alat pengajaran yang mendukung.

2. Tahap kegiatan dan pelaksanaan

Pelaksanaan kegiatan belajar mengajar untuk siklus III

\section{c. Siklus III}

1. Tahap perencanaan

Pada tahap ini peneliti mempersiapkan perangkat pembelajaran yang terdiri dari rencana pelajaran 3, LKM 3, soal tes dilaksanakan pada tanggal 25 Maret 2013 di kelas RS1 dengan jumlah mahasiswa 50 orang. Dalam hal ini peneliti bertindak sebagai dosen. Adapun proses belajar mengajar mengacu pada rencana pembelajaran 
dengan memperhatikan revisi pada siklus II, sehingga kesalahan atau kekurangan pada siklus II tidak terulang lagi. Observasi dilaksanakan bersamaan dengan pelaksanaan belajar mengajar. Pada akhir proses pembelajaran mahasiswa diberi tes formatif III dengan tujuan untuk mengetahui tingkat keberhasilan mahasiswa. Adapun data hasil penelitian pada siklus III adalah sebagai berikut:

Tabel 1.3

Hasil Tes Formatif Mahasiswa Pada Siklus III

\begin{tabular}{|c|c|}
\hline No & Nilai \\
\hline 1 & 85 \\
\hline 2 & 80 \\
\hline 3 & 80 \\
\hline 4 & 100 \\
\hline 5 & 100 \\
\hline 6 & 80 \\
\hline 7 & 85 \\
\hline 8 & 85 \\
\hline 9 & 100 \\
\hline 10 & 80 \\
\hline 11 & 80 \\
\hline 12 & 90 \\
\hline 13 & 100 \\
\hline 14 & 90 \\
\hline 15 & 100 \\
\hline 16 & 85 \\
\hline 17 & 100 \\
\hline 18 & 75 \\
\hline 19 & 75 \\
\hline 20 & 95 \\
\hline 21 & 95 \\
\hline 22 & 100 \\
\hline 23 & 95 \\
\hline 24 & 95 \\
\hline 25 & 95 \\
\hline
\end{tabular}

Jumlah Skor 4585

Jumlah Skor Maksimal 5000

Rata-Rata Skor Tercapai 4585/5000

$=91,7$

\begin{tabular}{|c|c|}
\hline No & Nilai \\
\hline 26 & 95 \\
\hline 27 & 85 \\
\hline 28 & 75 \\
\hline 29 & 85 \\
\hline 30 & 90 \\
\hline 31 & 90 \\
\hline 32 & 80 \\
\hline 33 & 90 \\
\hline 34 & 100 \\
\hline 35 & 100 \\
\hline 36 & 100 \\
\hline 37 & 100 \\
\hline 38 & 100 \\
\hline 39 & 100 \\
\hline 40 & 100 \\
\hline 41 & 100 \\
\hline 42 & 100 \\
\hline 43 & 100 \\
\hline 44 & 100 \\
\hline 45 & 85 \\
\hline 46 & 85 \\
\hline 47 & 100 \\
\hline 48 & 95 \\
\hline 49 & 95 \\
\hline 50 & 90 \\
\hline & \\
\hline
\end{tabular}

Berdasarkan tabel 1, 2, dan 3 dapat disimpulkan bahwa terdapat peningkatan rata-rata skor tercapai. Pada tabel 2 diketahui rata-rata skor 
tercapai adalah 82,1, skor tersebut meningkat dari rata-rata skor tercapai pada siklus 1 yaitu 75,4. Pada siklus III terjadi peningkatan rata-rata skor hingga 91,7. Adanya peningkatan hasil belajar pada setiap siklus dimungkinkan karena mahasiswa sudah terbiasa dengan metode pembelajaran kooperatif menggunakan LKM sehingga lebih mudah memahami materi yang diberikan.

\section{Refleksi}

Pada tahap ini dikaji apa yang telah terlaksana dengan baik maupun yang masih kurang dalam proses pembelajaran dengan metode kooperatif melalui penerapan LKM. Dari data-data yang telah diperoleh dapat duraikan sebagai berikut:

1. Berdasarkan data hasil pengamatan diketahui bahwa siswa aktif selama proses belajar berlangsung.

2. Setiap siklus mengalami peningkatan skor rata-rata tercapai yang menandakan terjadinya penambahan pemahaman materi yang lebih baik.

\section{Revisi Pelaksanaan}

Pada siklus III dosen menerapkan metode kooperatif melalui penerapan LKM dengan baik dilihat dari aktivitas mahasiswa serta hasil evaluasi pembelajarannya. Maka tidak diperlukan revisi terlalu banyak, tetapi yang perlu diperhatikan untuk tindakan selanjutnya adalah memaksimalkan dan mempertahankan apa yang telah ada dengan tujuan agar pada pelaksanaan proses pembelajaran melalui metode kooperatif dengan penerapan LKM dapat meningkatkan proses pembelajaran sehingga tujuan pembelajaran dapat tercapai.

\section{PEMBAHASAN}

\section{Peningkatan skor rata-rata tercapai}

Melalui hasil peneilitian ini menunjukkan bahwa pendekatan metode kooperatif melalui LKM berdampak positif dalam meningkatkan prestasi belajar mahasiswa. Hal ini dapat dilihat dari semakin tingginya pemahaman mahasiswa terhadap materi yang disampaikan pada setiap siklus yang ditandai dengan pencapaian skor rata-rata pada masingmasing siklus yaitu 75,4, 82,1, dan 91,7.

\section{Aktivitas dosen dan mahasiswa dalam pembelajaran}

Aktivitas dosen dan mahasiswa dalam proses pembelajaran biostatistik yang paling dominan adalah bekerja dengan menggunakan alat/media, mendengarkan/ memperhatikan penjelasan dosen, dan diskusi antar mahasiswa/dosen secara aktif. Aktivitas dosen di antaranya membimbing dan mengamati mahasiswa dalam mengerjakan LKM/ menemukan konsep, menjelaskan/melatih menggunakan alat, dan memberi umpan balik/evaluasi/tanya jawab.

\section{KESIMPULAN DAN SARAN}

\section{Kesimpulan}

Dari hasil kegiatan pembelajaran yang telah dilakukan selama tiga siklus, dan 
berdasarkan seluruh pembahasan serta analisis yang telah dilakukan dapat disimpulkan sebagai berikut:

1. Pembelajaran dengan pendekatan metode kooperatif melalui media LKM memiliki dampak positif dalam meningkatkan prestasi belajar mahasiswa yang ditandai dengan peningkatan rata-rata skor tercapai dalam setiap siklus, yaitu siklus I $(75,4)$, siklus II $(82,1)$, siklus III $(91,7)$.

2. Penerapan pendekatan metode kooperatif melalui media LKM dapat meningkatkan minat dan motivasi belajar mahasiswa yang ditunjukan dengan meningkatnya aktivitas diskusi di dalam kelas.

\section{Saran}

1. Untuk melaksanakan pendekatan metode kooperatif melalui media LKM memerlukan persiapan yang cukup matang, sehingga dosen harus mampu menentukan skenario pembelajaran yang benar-benar bisa diterapkan sehingga diperoleh hasil yang optimal.

2. Dalam rangka meningkatkan prestasi belajar, dosen hendaknya lebih sering melatih mahasiswa dengan berbagai metode pembelajaran, walau dalam taraf yang sederhana, dimana mahasiswa nantinya dapat menemukan pengetahuan baru, memperoleh konsep dan keterampilan, sehingga mahasiswa mampu memecahkan masalah-masalah yang dihadapinya.

\section{DAFTAR PUSTAKA}

Bloom B. S. (1956). Taxonomy of Educational Objectives, Handbook I: The Cognitive Domain. New York: David McKay Co Inc.

Dimyati \&Mudjiono.2006. Belajar dan Pembelajaran. Jakarta: PT. Rineka Cipta.

Kamus Besar Bahasa Indonesia (KBBI), 1996.

Kemmis, S. dan Mc. Taggart, R. 1988. The Action Research Planner. Victoria Dearcin University Press.Dahar, R.W. 1989. Teori-teori Belajar. Jakarta: Erlangga.

Mukhlis, Abdul. (Ed.). 2000. Penelitian Tindakan Kelas. Makalah Panitia Pelatihan Penulisan Karya Ilmiah untuk Guru.

Pengenalan Sistem Akademik Universitas. 2008. Panduan Kegiatan Mahasiswa Baru Universitas Indonesia Tahun Akademik 2008/2009. Depok. UI Press.

Soetomo. 1993. Dasar-dasar Interaksi Belajar Mengajar. Usaha Nasional Surabaya.

Undang-undang No. 20 Tahun 2003 tentang Pendidikan Nasional.

Witjaksono, Mit. 1985. Konsep Strategi Pendekatan Pengelolaan Kelas. P3T IKIP Mal 


\title{
BERBAGI PENGETAHUAN SEBAGAI ALTERNATIF PENCIPTAAN PENGETAHUAN UNTUK STAF PENGAJAR VOKASI UI
}

\author{
Dyah Safitri ${ }^{1 *}$

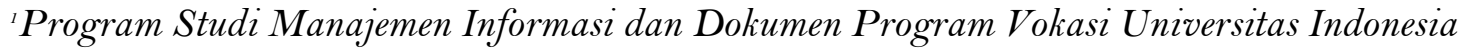

\begin{abstract}
ABSTRAK - Proses berbagi pengetahuan menjadi proses penting bagi sebuah organisasi dalam menciptakan pengetahuan dan inovasi baru. Pengetahuan yang bersifat tacit dan explicit dapat dipindahkan melalui beberapa proses berbagi pengetahuan. Budaya menjadi bagian penting dalam proses tersebut terutama penghargaan terhadap sumber pengetahuan yang bersedia membagi pengetahuannya. Pada organisasi pendidikan seperti Program Vokasi UI yang belum lama berdiri seharusnya pelembagaan penyeleksi pengetahuan seperti knowledge centre akan bermanfaat dalam proses berbagi pengetahuan.
\end{abstract}

Kata kunci: Pengetahuan, Berbagi Pengetahuan, Pengetahuan Tacit, Pengetahuan Eksplisit, Pemindahan Pengetahuan, Pengelola Pengetahuan, Pusat Pengetahuan.

ABSTRACT -The process of knowledge sharing becomes important processes for an organization in creating new knowledge and innovation. Tacit and explicit knowledge can be moved through several processes to knowledge sharing. Culture an important part of the process, especially an appreciation of the sources of knowledge that is willing to share the knowledge. In educational organizations especially recently established such as Vocational Program UI should institutionalization of knowledge as a knowledge center will be beneficial in the process of knowledge sharing.

Keywords: Knowledge, Knowledge Sharing, Tacit Knowledge, Explicit Knowledge, Knowledge Transfer, Knowledge Manager, Knowledge Center

\section{PENDAHULUAN}

\section{Latar Belakang}

Di dalam sebuah organisasi, pengetahuan adalah salah satu aset paling bernilai dan faktor penting dalam kompetisi. Siakas dan Giorgiadou (2008) berpendapat bahwa organisasi menempatkan pengetahuan sebagai faktor penting di dalam pembentukan, penggunaan, dan distribusi informasi untuk memperkuat modal pengetahuan di dalam organisasi tersebut dalam persaingan global. Kemampuan organisasi dalam belajar, beradaptasi, dan berubah menjadi kompetensi inti untuk tetap bertahan dalam persaingan. Organisasi yang sukses adalah organisasi yang berhasil menciptakan pengetahuan baru, menyebarkannya di dalam organisasi dan mendorong penciptaan produk dan layanan baru.

Tidak banyak organisasi yang mengetahui dan sadar bahwa terdapat potensi pengetahuan tersembunyi di dalam organisasi. Setiarso et.al (2008) menyatakan bahwa Delphi Group pada tahun 1997 melakukan riset tentang komposisi pengetahuan yang tersimpan pada $42 \%$ di pikiran karyawan, $26 \%$ dalam dokumen kertas, 20\% dalam 
dokumen elektronik, dan $12 \%$ dalam knowledge-base elektronik. Pengetahuan yang tersimpan di dalam pikiran anggota organisasi adalah tacit knowledge. Menurut Filos (2008) tacit knowledge bersifat personal, kombinasi antara pengalaman dan intuisi, dan tidak banyak perusahaan dapat meng-capture dan mengkomunikasikan pengetahuan tersebut. Komitmen individu di dalam organisasi menjadi faktor penentu tersebarnya tacit knowledge di dalam organisasi, sehingga perlu diciptakan kepercayaan dan loyalitas di antara individu dan organisasi. Setiarso et.al (2008) menyatakan tacit knowledge memang sangat sulit dibagi ke orang lain, dan dokumentasi menjadi faktor penting dalam mengubah tacit knowledge menjadi explicit knowledge. Tanpa dokumentasi, tacit knowledge tidak akan berarti dan menjadi sulit diakses oleh siapapun dan kapanpun di dalam organisasi.

Agar pengetahuan tetap memberi manfaat dalam jangka panjang, sebuah organisasi harus menyadari keberadaan karyawan, pencipta pengetahuan, dan penggunanya agar berbagi pengetahuan (knowledge sharing) dapat berjalan efektif dan inovasi dapat terus muncul. Menurut Saenz, Aramburu, dan Rivera (2010) penciptaan pengetahuan merupakan proses berkelanjutan dari seorang individu yang memiliki keterbatasan pengetahuan kemudian memperoleh pengetahuan baru. Dengan interaksi dan berbagi pengetahuan antar individu, individu tersebut akan memiliki pandangan dan pengetahuan baru untuk menghadapi masalah yang akan terjadi. Pada level organisasi -termasuk juga pada organisasi pendidikan- dorongan pada penciptaan pengetahuan dan inovasi pribadi akan membentuk penciptaan pengetahuan dan inovasi baru.

Sebagai salah satu organisasi pendidikan, Program Vokasi Universitas Indonesia merupakan organisasi baru yang dimulai pada 2008. Pengelolaan administasi program pendidikan vokasi dilakukan secara terpusat di Universitas Indonesia menggantikan program diploma III yang tersebar di berbagai fakultas dan sudah ada sejak tahun 1980-an. Tujuan menyatukan program tersebut adalah efisiensi mengingat banyaknya jalur pendidikan yang ada di UI serta untuk merealisasikan visi UI menjadi universitas riset kelas dunia dalam menghadapai tantangan global. Program vokasi UI merupakan kumpulan dari berbagai disiplin ilmu eksakta, sosial, ekonomi, hingga kesehatan dan kedokteran. Program pendidikan vokasi bertujuan menyiapkan peserta didik menjadi anggota masyarakat yang memiliki kemampuan tenaga ahli profesional dalam menerapkan, mengembangkan, dan menyebarluaskan teknologi dan/atau kesenian serta mengupayakan penggunaannya untuk meningkatkan taraf kehidupan masyarakat dan memperkaya kebudayaan nasional. Secara khusus, program diploma diarahkan untuk menghasilkan lulusan yang menguasai kemampuan dalam bidang kerja tertentu sehingga dapat langsung diserap sebagai tenaga kerja di industri/swasta, lembaga pemerintah atau berwiraswasta secara 
mandiri, hal ini karena beban pengajaran pada program pendidikan vokasi telah disusun lebih mengutamakan beban mata kuliah keterampilan (60\%) dibandingkan dengan beban mata kuliah teori. Visi Program Vokasi UI adalah menjadi pusat unggulan pendidikan vokasional di ASEAN. Misinya adalah Menyelenggarakan pendidikan vokasional dengan penekanan pada keahlian (skilled) dan praktek selaras dengan kebutuhan dunia kerja dan industri untuk menghasilkan tenaga ahli profesional yang berstandar internasional, mengembangkan bidang-bidang vokasional dalam upaya untuk meningkatkan taraf kehidupan dan kualitas masyarakat Indonesia, serta mengembangkan kerjasama antar lembaga/instansi di dalam dan luar negeri untuk kepentingan pendidikan, praktek kerja dan adaptasi kurikulum. (Vokasi, 2013)

Sebagai organisasi yang baru dengan membawahi pendidikan dengan lingkup rumpun ilmu yang beragam, berbagi pengetahuan untuk staf pengajar atau dosen di program vokasi UI menjadi sangat penting. Berbagai pengalaman yang diperoleh dari sebuah rumpun ilmu misalnya dapat dibagi ke dalam internal organisasi sehingga dapat dengan mudah diadaptasi oleh rumpun ilmu lainnya. Dengan budaya berbagi pengetahuan, akan lebih cepat dipetakan kekuatan program studi vokasi karena kekurangan pada program studi dapat saling terisi. Di samping itu, perkembangan ilmu dan pengayaan mata kuliah di berbagai rumpun ilmu dapat berkembang dengan lebih baik.

\section{ANALISIS DAN PEMBAHASAN}

\section{Pengetahuan}

Davenport dan Prusak (1998) menyebut pengetahuan sebagai pengalaman, nilai-nilai, konteks dan wawasan yang tercampur sehingga menyediakan sebuah kerangka kerja untuk mengevaluasi dan menghubungkan pengalaman-pengalaman dan informasi baru. Kedua peneliti itu menemukan bahwa di dalam organisasi, pengetahuan kerap menjadi artefak yang melekat seperti dokumen, video, audio atau penyimpanan di dalam rutinitas, proses, praktek, dan norma-norma organisasi. Mereka juga melihat bahwa pengetahuan akan bernilai apabila ada tambahan konteks, budaya, pengalaman, dan interpretasi dari orang lain. Nonaka (1994) melihat pengetahuan dalam arti yang lebih spesifik. Pengguna pengetahuan harus mengerti dan melihat pengalaman dengan konteks yang ada, kondisi dan pengaruh yang melingkupi, sehingga pengetahuan dihasilkan dan berarti untuk mereka.

Nonaka dan Takeuchi menggambarkan dua tipe pengetahuan yaitu pengetahuan tacit (tacitknowledge) dan pengetahuan eksplisit (explicit knowledge).

- Tacit knowledge adalah pemahaman yang ada di dalam pikiran pemilik pengetahuan dan tidak secara langsung dapat dimunculkan dalam bentuk data atau representasi pengetahuan sehingga kerap disebut pengetahuan yang tidak terstruktur. 
- Explicit knowledge yaitu pengetahuan yang secara langsung berbentuk pengetahuan dan umumnya disebut sebagai pengetahuan terstruktur. Sehingga, pengetahuan adalah gabungan antara kedua pengetahuan tersebut.

\section{Pemindahan Pengetahuan}

Nonaka dan Takeuchi menawarkan empat model pemindahan pengetahuan (knowledge transfer) sebagai model SECI (Socialization, Externalization, Combination, Internalization). Keempatnya adalah :

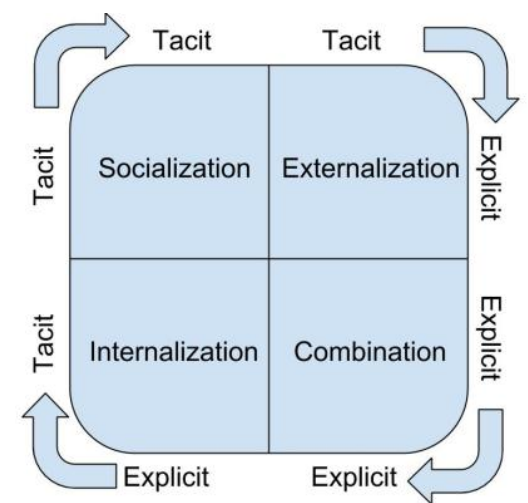

Sumber : Nonaka dan Takeuchi (1995)

Gambar 1. 1

SECI Model

- Socialization adalah proses berbagi pengetahuan dan membuat tacit knowledge sebagai model mental dan keterampilan teknis. Tacit knowledge dapat diperoleh melalui observasi, imitasi, dan praktek.

- Externalization adalah proses artikulasi tacit knowledge dalam bentuk konsep eksplisit berwujud metafora, analogis, hipotesis, atau model
- Combination adalah proses konsep sistemis ke dalam sistem pengetahuan dengan menggabungkan expilicit knowledge yang berbeda. Explicit knowledge dipindah melalui media seperti dokumen, pertemuan, email atau percakapan telepon. Kategorisasi pengetahuan ini akan memunculkan pengetahuan baru.

- Internalization adalah proses mengubah explicit knowledge menjadi tacitknowledge dan dekat dengan konsep pengalaman karena mengerjakan atau dapat disebut sebagai learning by doing

Keempat proses tersebut memperlihatkan bahwa perpindahan pengetahuan bergantung pada pemahaman antara pemilik pengetahuan dan pengguna pengetahuan. Pemahaman umum terdiri atas konteks dan pengalaman. Konteks adalah cerita di balik pengetahuan, kondisi atau situasi yang membuat pengetahuan dapat dimengerti. Sedangkan pengalaman adalah aktivitas yang memproduksi model mental bagaimana pengetahuan digunakan.

\section{Berbagai Pengetahuan}

Gupta, Sharma, Hsu (2008) berpendapat kemampuan organisasi melakukan perpindahan informasi dan pengetahuan adalah faktor penentu bagi organisasi dalam mempertahankan keunggulan kompetitifnya. Aliran informasi dan pengetahuan terjadi ketika tacit knowledgedan explicit knowledge dibedakan dalam proses pemindahannya. Transfer knowledge adalah aspek terpenting 
dari manajeman pengetahuan (knowledge management) saat pengetahuan diambil atau didapatkan dari sebuah organisasi sehingga harus dapat dibagikan dari pribadi dan kelompok di dalam organisasi tersebut.

Definisi berbagai pengetahuan datang dari Dixon (2000). Menurutnya ada lima tipe utama berbagi pengethuan yaitu serial, near, far, strategic, dan expert transfer. Masingmasing dibedakan menurut tujuan, metode, dan cara menggunakannya. Adapun lima tipe utama tersebut yaitu :

1. Serial Transfer: diterapkan ke sebuah tim yang mengerjakan satu tugas, kemudian tim yang sama mengulang tugas tersebut dalam konteks baru. Contohnya adalah tim pengganti generator uap di Bechtel (sebuah perusahaan konstruksi terkenal dari Amerika Serikat). Tim ini mengganti sebuah generator di sebuah lokasi spesifik, misalnya di perusahaan kimia, selama dua atau tiga bulan. Ketika tim menyelesaikan tugas tersebut, pekerjaan tim lantas berpindah ke kilang minyak untuk mengganti generator. Tim menggunakan kembali pengetahuan yang didapatkan dari mengerjakan perusahaan kimia. Pada serial transfer, tim sumber dan tim penerima adalah tim yang sama. Serial transfer menawarkan efisiensi dalam kecepatan dan kualitas.

2. Near transfer: melibatkan transfer pengetahuan dari tim sumber ke tim penerima yang mengerjakan pekerjaan serupa dalam konteks sama tetapi di lokasi berbeda. Syarat utamanya adalah pekerjaan tersebut merupakan pekerjaan besar dan terus menerus. Sebuah contoh adalah tim pekerja Ford di Chicago dan di Atlanta. Di Atlanta tim pekerja dapat memasang rem depan mobil baru 15 detik lebih cepat dibanding tim pekerja di Chicago. Kemudian, tim pekerja Ford di Chicago menggunakan pengetahuan tim pekerja di Atlanta untuk dapat memasang rem depan supaya mendapatkan waktu yang sama. Near transfer membawa explicit knowledge dari satu lokasi ke lokasi lainnya.

3. Far transfer : melibatkan pemindahan tacit knowledge dari tim sumber ke tim penerima ketika pengetahuan berkaitan dengan tugas non-rutin. Contohnya adalah tim ekplorasi minyak mengundang tim lain untuk membantu menginterpretasi data seismik dan geologi yang telah mereka kumpulkan. Pengetahuan ditransfer langsung ke masing-masing anggota tim terutama pada langkah dan prosedur yang tidak tertulis. Karena interpretasi dari data tersebut adalah tugas dengan beragam variabel, mereka harus menyajikan sesuai dengan pengetahuan mereka. Far transfer biasa digunakan untuk memungkinkan pemindahan pengetahuan yang sangat spesifik.

4. Strategic transfer melibatkan pemindahan pengetahuan yang sangat kompleks, seperti bagaimana merilis sebuah produk dari satu tim ke tim lain yang terpisah baik tempat maupun waktu. Transfer ini berbeda dari far transfer karena strategic transfer lebih terbatas lingkupnya seperti pada satu tim tertentu. Biasanya strategic transfer akan bermanfaat bagi perusahaan 
berskala global ketika pengetahuan bisa dipindahkan ke lokasi cabang di belahan dunia lain dengan konteks lingkungan yang berbeda.

5. Expert Transfer, melibatkan pemindahan explicit knowledge mengenai tugas yang dikerjakan rutin. Contohnya adalah teknisi yang mengirim surat elektronik ke jaringan pertemanannya untuk bertanya bagaimana meningkatkan kecerahan monitor kuno dan mendapatkan jawaban dari ahli yang mendalami bidang tersebut.
Di dalam model transfer ini, kebutuhan keahlian dapat menjawab berbagai pertanyaan yang diajukan.

Jacobson (2008) menekankan bahwa dalam memahami berbagi pengetahuan harus mengerti apa yang terjadi di level individu sebagai pusat dari proses tersebut. Jacobsonmenawarkan model knowledge sharing yang diadaptasi dari model proses komunikasi Shannon Weaver dan Barlo. Model yang ditawarkan oleh Jacobson adalah sebagai berikut:

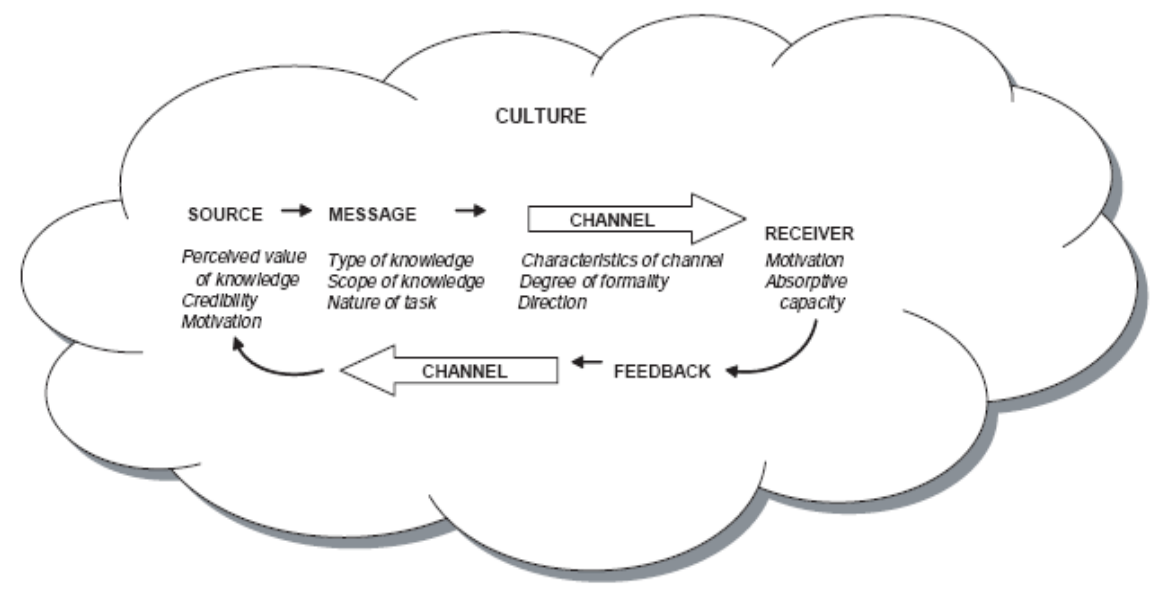

Sumber : Jacobson (2008)

Gambar 1.2

Model knowledge sharing Jacobson

Ada enam faktor utama yang dapat dilihat dalam proses berbagi pengetahuan

1. Sumber pengetahuan yaitu individu yang memiliki pengetahuan dan memindahkan pengetahuan tersebut ke orang lain. Ada tiga karakteristik sumber pengetahuan yaitu :

a. Aliran pengetahuan antar individu diasosiasikan dengan biaya, maka pemilik pengetahuan dianggap lebih bernilai dibanding yang tidak memiliki.

b. Kredibilitas sumber pengetahuan, ini berhubungan dengan kompetensi seseorang untuk membagi pengetahuan yang dimilikinya.

c. Motivasi dari sumber pengetahuan untuk bersedia berbagi karena yang memiliki pengetahuan biasanya 
memiliki status kekuasan lebih besar di organisasi.

2. Pesan. Jacobson melihat bahwa jenis pengetahuan dan cakupan pengetahuan seperti apa yang akan dibagi dalam organisasi.

3. Penerima pengetahuan. Pada proses berbagi pengetahuan, efektivitasnya bergantung pada motivasi dan kapasitas menyerap dari penerima pengetahuan. Motivasi lebih pada persoalan pemahaman menggunakan pengetahuan dari sumber lain. Sedangkan kapasitas menyerap pengetahuan baru adalah bagaimana pengetahuan tersebut dapat digabungkan dengan pengetahuan yang dimiliki.

4. Kanal komunikasi atau bagaimana pengetahuan dikomunikasikan. Ada sejumlah kanal yang dapat digunakan untuk berbagi pengetahuan mulai dari pertemuan tatap muka langsung, hingga menggunakan jalur teknologi informasi (internet, email, forum diskusi, hingga portal berbagi pengetahuan). Kanal komunikasi ini bisa bersifat formal dan non-formal.

5. Umpan balik. Berbagi pengetahuan dapat terlihat apabila ada respon verbal maupun non-verbal dari penerima pengetahuan yang menandakan penerima mengerti pesan yang diterima.

6. Budaya organisasi. Budaya yang direfleksikan ke dalam nilai-nilai organisasi, norma-norma, dan dipraktekkan dalam kegiatan sehari-hari di sebuah organisasi. Ada empat aspek yang dapat dilihat bagaimana budaya dapat memengaruhi knowledge sharing, yaitu :

a. Ukuran asumsi budaya yang melihat pengetahuan sebagai sesuatu yang penting

b. Budaya menjadi mediasi di antara pengetahuan individu, kelompok, dan organisasi

c. Budaya menciptakan konteks organisasi dalam interaksi sosial

d. Budaya berdampak pada penciptaan dan adopsi pengetahuan baru.

Satu nilai yang disebutkan oleh Jacobson sebagai bagian budaya berbagi pengetahuan adalah kepercayaan, yakni ada penghormatan kepada pemilik ide. Hal ini diharapkan agar dalam proses berbagi pengetahuan, orang yang memberi pengetahuan baru harus mendapat penghargaan dan balasan setara. Kepercayaan harus transparan atau dapat dilihat dimana-mana dan harus dimulai dari jajaran manajemen teratas. Secara khusus, manajemen teratas harus melakukan hal tersebut karena kegiatan mereka didefinisikan sebagai nilai-nilai dalam organisasi.

Untuk proses berbagi pengetahuan untuk staf pengajar di Program Vokasi UI sebagai alternatif penciptaan pengetahuan, model Jacobson dan Dixon dapat diadaptasi dalam pelaksanaan. Penulis menawarkan model pengembangan sebagai berikut : 


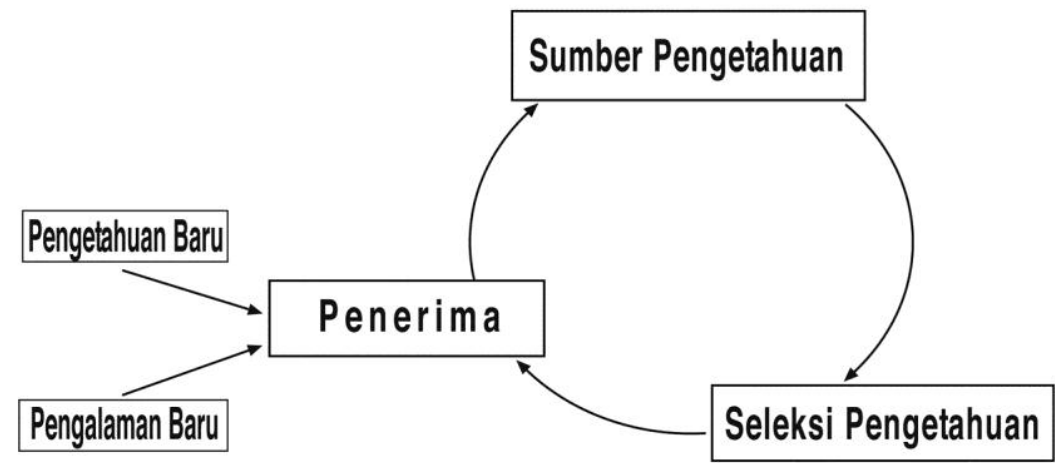

Gambar 1.3

Model Berbagi Pengetahuan Untuk Staf Pengajar di Program Vokasi UI

Proses ini terbentuk dalam siklus yang berulang. Sumber pengetahuan dapat berupa pengetahuan staf pengajar Vokasi UI yang bersifat tacit dan explicit. Pada tingkatan rumpun program studi, pengetahuan tacit dan eksplisit dapat dialirkan kepada penerima menjadi pengetahuan baru bagi program studi lainnya di lingkungan Program Vokasi UI.

Pada tahapan seleksi pengetahuan perlu ada lembaga yang dapat memilah dan memilih pengetahuan apa saja yang dapat dialirkan ke dalam organisasi. Lembaga ini dapat berupa perorangan yang ditunjuk untuk mengelola aktivitas berbagi pengetahuan seperti manajer pengetahuan (knowledge manager). Lembaga ini juga dapat menjadi bagian dari organisasi dan diberi fungsi dan wewenang melakukan seleksi pengetahan yang akan dialirkan. Lembaga penyeleksi ini berperan penting apakah nantinya pengetahuan tersebut dapat dipindahkan melalui metode yang tepat apakah menggunakan pendekatan near, serial, far, strategic ataupun expert transfer saat mengalirkan pengetahuan. Pemakaian media apa saja dalam membagi pengetahuan baru juga menjadi tanggung jawab dari lembaga penyeleksi ini. Lembaga yang menjadi bagian dari struktur organisasi dapat berupa pusat pengetahuan (knowledge center) yang dikelola profesional.

Pada penerima pengetahuan, dapat diartikan sebagai staf pengajar sebagai profesional maupun lembaga yaitu berbagai program studi di Program Vokasi UI. Penerima akan menerima pengetahuan baru yang mengalir dari penyeleksi pengetahuan. Selanjutnya mereka akan memberi makna dan pengalaman baru pada pengetahuan tersebut. Setelah memberi makna dan pengalaman baru pada pengetahuan yang telah dialirkan oleh lembaga penyeleksi maka pengetahuan baru akan terbentuk. Proses ini berlaku terus menerus dan membentuk siklus yang tidak terhenti sehingga proses berbagi pengetahuan akan menjadi bagian tak terpisahkan dari jalannya organisasi.

\section{KESIMPULAN}

Berbagi pengetahuan adalah proses penting di dalam sebuah organisasi dalam mengelola dan menciptakan pengetahuan 
baru. Pada organisasi baru seperti pada Program Vokasi UI, penting untuk mengelola pengetahuan sejak dini. Pelembagaan berbagi pengetahuan seperti melalui orang yang bertanggung jawab pada mengalirnya pengetahuan (knowledge manager) maupun yang berbentuk dalam struktur organisasi seperti pusat pengetahuan (knowledge center) menjadi demikian penting agar penciptaan pengetahuan baru dapat berlangsung mudah dan terus menerus. Penambahan pengetahuan dan pengalaman baru yang dimiliki oleh staf pengajar sebagai profesional maupun rumpun program studi nantinya akan membentuk pengetahuan baru yang nanti akan terus dialirkan ke semua staf pengajar maupun rumpun program studi lainnya.

Proses berbagi pengetahuan adalah proses terus menerus dan berlangsung melekat dengan berlangsungnya organisasi. Organisasi dapat memanfaatkan pengetahuan yang berlimpah seperti pengetahuan di organisasi pendidikan. Setelah melalui proses siklus tersebut, organisasi pendidikan tentu akan memperoleh manfaat dari proses berbagi pengetahuan tersebut apabila prosesnya berjalan lancar dan terlembagakan.

\section{DAFTAR PUSTAKA}

Davenport, T. H. \& Prusak, L. (1998). Working Knowledge: How Organizations Manage What They Know. Boston : Harvard Business School Press.

Dixon, N. M. (2000). Common Knowledge: How Companies Thrive by Sharing What They Know. Boston: Harvard Business School Press.

Filos, Erastos (2008). Smart Organization in The Digital Age. In Jennex, Murray E. (Ed). Knowledge Management : Concept, Methodologies, Tools, and Application. (vol. 1, pp.48-72). Hershey : Information Science Reference.

Gupta,J., Sharma,SK.,Hsu, J. (2008). An Overview of Knowledge Management. In Jennex, Murray E (Ed). Knowledge Management : Concept, Methodologies, Tools, and Application. (vol. 1, pp. 1-22). Hershey : Information Science Reference.

Jacobson, Carolyn (2008) Knowledge Sharing Between Individual. In Jennex, Murray E. (Ed). Knowledge Management : Concept, Methodologies, Tools, And Application. (vol. 3. pp 1633-1641). Hershey : Information Science Reference

Nonaka, I. \& Takeuchi, H. (1995). The Knowledge-Creating Company: How Japanese Companies Create the Dynamics Innovation New York: Oxford University Press.

Saenz, J.,Aramburu,N.,Rivera,O. (2010) Exploring the Links between Structural Capital, Knowledge Sharing, Innovation Capability, and Business Competitiveness : An Empirical Study. In Harorimana, Deogratius (Ed). Cultural Implications of Knowledge Sharing, Management and Transfer.(pp.32 1-354). Pennsylvania : Information Science Reference.

Setiarso, Bambang., et.al (2009). Penerapan Knowledge Manajemen Pada Organisasi. Yogyakarta : Graha Ilmu. 
Siakas, Kerstin dan Georgiadou, Elli (2008). Knowledge Sharing in Virtual and Networked Organisations in Different Organisational and National Cultures. In Bolisani, Ettore (Ed) Building The Knowledge Society in The Internet. Sharing and Exchanging Knowledge in Networked Environments (pp 45- 64).Hersey : Information Science Reference.

Tentang Program Vokasi.http://vokasi.ui.ac.id/web/?page id=414 [15 November 2013] 